\title{
Prisoners' Attitudes toward Using Distance Education Whilst in Prisons in Saudi Arabia
}

\author{
Abdulkarim A. Al Saif \\ University of Qassim, Saudi Arabia
}

alsaif@manahij.net

\begin{abstract}
This research explores prisoners' attitudes for undertaking distance-learning courses whilst in prison, and considers both the benefits and the difficulties experienced by prisoners as a result of their academic work. It is based on over 35 questionnaires completed by 300 current prisoners. The research was conducted in three prisons throughout the country in three different provinces. In addition to providing an in-depth account of the role that education can play during a prison sentence and beyond, it is intended that the experiences shared by these prisoners will provide the basis for additional guidance and support for future distance-learning inmates. The data of this study show that the prisoners in general demonstrated positive attitudes toward using distance education whilst in prisons. The remarkable finding was that the prisoners were self-motivated to engage in the computer and Internet use to continue their academic studies whilst in prison and learn new skills for getting jobs after prison. This finding supports the possibility of the prisoners' engagement in distance education courses offered at prisons.
\end{abstract}

Keywords: distance education, attitude toward distance education, prisoners, motivating factors, inhibiting factors.

\section{Introduction}

Most courtiers around the world, attempt to educate inmates in prison so that they will be something other than inmates during subsequent phases of their lives. Offenders come to prison with much less education than the general population. This lower education level did not compel these persons to commit crimes, but it is a factor in the criminal's decision-making process. It creates a context in which an individual sees limited options, and therefore, does not believe that he or she has much to lose. Also, lack of education often is associated with a lack of regard for self, manifested in limited respect for others and institutions. According to Johnson (2001), a number of studies confirmed that educational programs are directly responsible for recent rise in the dropout rate and the decrease in crimes because many of those who drop out of high school or fail to qualify for admission to college or university do not possess the skills necessary to compete for jobs.

Material published as part of this publication, either on-line or in print, is copyrighted by the Informing Science Institute. Permission to make digital or paper copy of part or all of these works for personal or classroom use is granted without fee provided that the copies are not made or distributed for profit or commercial advantage AND that copies 1) bear this notice in full and 2) give the full citation on the first page. It is permissible to abstract these works so long as credit is given. To copy in all other cases or to republish or to post on a server or to redistribute to lists requires specific permission and payment of a fee. Contact Publisher@InformingScience.org to request redistribution permission.

\section{Statement of Problem}

In Saudi Arabia, there is a prison in each main city around the country provided with a number of classrooms and textbooks to provide a learning opportunity similar to the educational system applied outside prisons. Studying within whilst in prison is available for offenders who are interested to continue their education 
during subsequent phases beside others duties. Since this educational system inside prisons follows the overall educational system in the regular school, the learning opportunity, however, is not available for all the prisons specially those who have not attended schools before. In addition, learning and training opportunities in prisons are limited to certain subjects such as religious sessions, self-development sessions, electricity skills sessions, plumbing skills sessions which teach the basic skills of such subjects. Although, there is a lot of learning and training programs provided by some governmental agencies, schools, and community colleges, the offenders are not allowed to attend such opportunities. Therefore, this study attempts to close the gap between the prisoners and outside society by bridging learning and training opportunities to prisons. Thus, this study attempts to explore the opportunities and difficulties for applying distance education system at prison by examining the offenders' attitudes toward using distance education delivery system during subsequent phases. The distance system should provide the inmates with learning and training opportunities held outside the prison which would include formal and informal education.

\section{Distance Education for Prisoners}

In the literature, one may find that distance education has been defined from different perspectives over the years. As found in Simonson (1997), distance education can be defined as the application of telecommunications and electronic devices which enables students and learners to receive instruction that originates from some distance location. Today, distance education has become a popular technique in educational environments and communities and more accessible for every educational environments including level from K-12 to higher education. In addition, distance education can become a solution for instructional problems outside educational environments such as prisons. In prisons, prisoners can participate in educational programs outside the prisons, whilst in prison by utilizing distance education as a delivery system. Today, most of educational insinuations around the world have established their web courses using online pedagogical techniques such as chats, discussions, web-based testing, or simulation sites on the Internet in order to create new opportunities for their students (Eastmond, 2000). If prisoners have the ability to utilize technology effectively, they can use distance education course, either as an aid to promote learning in the traditional classroom, or as a distance education medium. In such environments, instructors can utilize technology such as Web-Based Instruction (WBI) to post course materials such as a course syllabus, course schedule and meetings, reading materials, and course requirements. They can also use WBI to test students' in-class learning on prison so that they can receive instant feedback in order to adjust their lecture plans. In some classes, instructors can use a stylus-based laptop, which incorporates the use of notes handwritten directly into the computer, when they lecture. At the end of each class, instructors can send their notes as e-mails to their students, which helps students focus on the lesson, rather than taking notes. The utilization of distance learning as a delivery system in prison, have a lot of advantages for the prisons themselves such as increasing their confidence and engagements in their societies, and enabling them to obtain degrees as an access to employment.

\section{Purpose of the Study}

The primary purpose of this study is to identify the attitude of inmates toward using distance education during subsequent phases of their lives in prisons in Saudi Arabia

The following research questions were addressed:

1. What are the relationships between selected inmates characteristics (demographics) including education background and inmates skills and access of technology (computer skills and access, Internet skills and access)? 
2. What are the relationships between selected inmates characteristics (demographics) including education background and inmates education whilst in prison?

3. What are the relationships between selected inmates characteristics (demographics) including education background and potential situations?

4. What are the relationships between selected inmates characteristics (demographics) including education background and distance education advantages?

5. What are the relationships between selected inmates characteristics (demographics) including education background and distance education disadvantages?

6. What are the relationships between selected inmates characteristics (demographics) including education background and training experiences?

\section{Methods}

The participants of this study included inmates $(n=300)$. These participants included female and male inmates from of three main prisons in three provinces; Riyadh, Makkah, Qassim. The inmates participating in this study were held for various periods of time in prisons starting from one year to fifteen years. The study used a survey research design for data collection. The data collected from the survey, was used to examine the relationship between the dependent, independent, and antecedent variables.

\section{Instrumentation}

The main instrument used for data collection was the survey which consists of seven parts.

Part I. Profile Characteristics. This part of survey consists of items (1-5) and they are to provide personal and professional characteristics of a participant in terms of age, gender, province, period, and education background.

Part II. Technology Skills and Access. This part consists of six items (6-11) and they are to provide information about the participants' computer skills and access. The participants rated their skills and access by using a 5 -point Likert scale ( $1=$ none and $5=$ too high).

Part III. Education in Prison This part consists of four items (12-15) and they are to provide information about the participants' education in prisons. The participants rated their education from: never study at prison to study until college graduation.

Part IV. Training Experiences: This part consists of three items (16-18) and they are to provide information about the training cycles that the participants have had in prisons which included computer training, plumbing training, electricity training, carpentry training, and others ( they state it).

Potential Situations. This part consists of five items (19-23) and they are to provide information about the attitude of the participants toward some potential situations in distance education. The participants rated their usage by using a 5 -point Likert scale $(1=$ strongly disagree, and $5=$ strongly agree).

Part V. Advantages of Distance Education. This part consists of six items (24-29) and they are to provide information about the attitude of the participants toward some advantages of distance education. The participants rated their usage by using a 5 -point Likert scale $(1=$ strongly disagree, and $5=$ strongly agree).

Part VI. Disadvantages of Distance Education. This part consists of six items (30-35) and they are to provide information about the attitude of the participants toward some disadvantages of 
distance education. The participants rated their usage by using a 5-point Likert scale $(1=$ strongly disagree, and $5=$ strongly agree).

\section{Data Analysis}

Through the survey used, a large amount data was collected in this study. The data obtained were analyzed based on their relationship to the research questions through these seven major components: participants' demographics and education background, computer and Internet skills and access, education whilst in prisons, training experiences, potential situations, and distance education advantages and disadvantages.

Accordingly, the data were analyzed through two types of analysis; descriptive analysis and inferential statistical analysis. In the descriptive analysis, the data analyses were accomplished by using measures of central tendency (mean) and measures of variability (standards deviation) as well as frequency distributions of the responses. The inferential statistical analyses were conducted to address the seven research questions and examine the relationships among the major components.

\section{Discussion}

In this study, it was found that there is relationship between computer and internet skills and use, and the prisoners' characteristics. It was found also that the computer and Internet skills and use were correlated with the age, which means that whenever the age increases, the technology skills and use decrease. This finding is compatible with what Gary (1997) found regarding the consequence of computer and Internet skills and use for using such technologies. It was also found that the technology skills and use were correlated with the gender, where the female prisoners have higher skills in using computer and Internet than their male mates. This finding could be explained that the nature of girls' majors in the study was purely scientific. This finding supports what Lindner, Murphy and Dooley (2001) found that female had the highest distance education value scores and stated a need for further research in this area.

This study found that the prisoners' attitude toward distance education advantages was positively correlated with their skills and use of computer and Internet. On the other hand, the attitude toward distance education disadvantages was negatively correlated with the technology skills and use. These findings led us to conclude that whenever a prisoner's skills and use of computer and Internet increase, his/her attitude toward using distance education increases and vise versa. In addition, the nature of study tasks that the prisoners involve in was found correlated with the technology skills and use.

In this study, it was found that the prisoners' attitudes toward distance education advantages were positively correlated with educational level variables, which means that prisoners have high level of education considered the distance education advantages. Moreover, distance education advantages were related to training tasks at prison.

The data show that the prisoners' educational level and training tasks were correlated with potential situations, distance education advantages, and disadvantages variables. This finding indicates that the type of tasks that a prisoner is approached to in prison, plays a great role in his/ her attitude toward distance education use. The correlation between educational level and training tasks and these variables supports what Murray (2001) found that there are many reasons why a prospective prisoner would choose to take online courses. However, it can be argued that the number one reason is flexibility. The ability to $\log$ on anytime day or night from practically anywhere is attractive. 


\section{Recommendations and Conclusions}

\section{Recommendations for the Interior Ministry}

As found in many studies mentioned earlier, attitude toward participation in distance education always is influenced by the lack of knowledge of the nature of distance learning. Therefore, the Interior Ministry, as the agency responsible for prisons in Saudi Arabia, could introduce distance education services to prisoners prior to starting the service to ensure more involvement into distance education activities. This introduction could be done by providing formal and informal seminars explaining the nature of the new paradigm. The Ministry could also initiate professional development process directed toward distance education by providing prisoners with awareness, seminars, and tutorial for distance education, prior implementing the system As it found in this study, the availability of a suitable infrastructure for distance learning programs was a significant factor for developing positive attitudes. Therefore, developing distance education infrastructure would be a very important factor for prisoners to participate in distance education program. Since Web-Based Instruction ( WBI) is the most popular distance learning style today, for most distance education programs, the Ministry can support the utilization of prisoners for distance education especially WBI by providing prisons with adequate technology such as systems reliability connectivity/access, hardware/software, and setup. The prisoners should be able to recognize technologies' strengths and weaknesses so they will be able to select the most appropriate ones for a particular lesson. Providing the prisons with sufficient introduction and reliable technology will be significant factor for successful implementation of distance education programs at prisons.

\section{Recommendations for Further Research}

1. The present study was limited to prisoners' attitude toward using distance education only. Interested investigators are, therefore, encouraged to a replicate this study with additional types of samples to include Interior Ministry administrators, faculty, and staff, beside the prisoners.

2. The current study concentrated on certain prisoners' attitude factors toward using distance education. It is recommended that future studies extend these factors by examining additional attitudes factors, even as they attend to the results of this study.

3. The factors of prisoners' attitude toward using distance education focused on this study could be explored further in different cultural contexts to see to what extent these cultures impact the adoption and implementation of distance education.

4. The current study used survey instrument only for collecting data; therefore, it would be appropriate if further researchers use additional tools such as using interview, observation, and focus groups.

\section{Conclusions}

Today, most instructional institutions around the world face new challenges and make new decisions in the several areas especially learning delivery systems. Prisons, as responsible agencies for prisoners' education, have to take the advantages of technology to offer education for prisoners whilst in prisons. The purpose of this study was to identify the prisoners' attitude toward using distance education in Saudi Arabia. Substantially, the findings of this study indicate opportunities for successful distance education implementation at the prisons if attention is given to certain issues. Thus, this study found that prisoners' attitude of distance education is influenced by a variety factors such as computer and Internet skills and access. The educational level and training tasks were found a critical factor in demonstrating positive attitude toward distance education use. 
The prisoners have demonstrated highly positive attitudes toward distance education use. They were in much agreement with the potential situations, distance education advantages. However, the prisoners were not in much agreement with distance education disadvantages. Encouraging such positive attitudes requires ultimate and efficient cooperation among the different levels of the Interior Ministry administration, and local universities and colleges, and all other relevant personnel. Effective and clear policies for distance education programs must be structured prior distance education implementation.

\section{Results}

The findings and discussion of this study will be published at a later date.

\section{References}

Arbaugh, J.B. (2001). How instructor immediacy behaviors affect student satisfaction and learning in webbased courses. Business Communication Quarterly, 64(4), 42-54.

Arfaj, A. (2001). The perception of college students in Saudi Arabia towards distance web-based instruction. Unpublished doctoral dissertation, Ohio University Main Campus, Athens.

Dick, W., Carey, L., \& Cary, O. (2004). The systematic design of instruction (6th ed.). Boston: Addison and Wesley Publishers.

Dooley, K., \& Murphrey, T. (2000). How the perspectives of administrators, faculty, and support units impact the rate of distance education adoption. Online Journal of Distance Learning Administration. Retrieved July 21, 2004, from: http://www.westga.edu/ distance/ojdla/winter34/winter34.htm

Eastmond, N., \& Du Plessis. (2000). An incremental approach to implement a web course. TechTrends, 44(3), 40-45.

Gary, S. (1997). Training teachers, faculty members, and staff. In B. H. Khan (Ed.), Web based instruction. Englewood Cliffs, NJ: Educational Technology Publications.

Johnson, J. (2001). Building bridges to the economic mainstream for African American male ex- offenders: A preliminary assessment of an inmate education re-entry program. Report Evaluation. North Carolina University, 2001.

Khan, B. (Ed.). (1997). Web-based instruction. Englewood Cliffs, NJ: Educational Technology Publications, Inc.

Lee, J. (2001). Instructional support for distance education and faculty motivation, commitment, satisfaction. British Journal of Educational Technology, 32, 2. Retrieved April 20, 2003, from the World Wide Web: ERIC database (EJ626765)

Lee, J. (2002). Faculty and administrator perceptions of instructional support for distance education. International Journal of Instructional Media, 29(1), 27-45.

Levine, T. (1992). Going the distance: A handbook for developing distance degree program using television courses and telecommunications technologies. Bethesda, MD.

Lin, H. (2002). Motivating and inhibiting factors that affect faculty participation in distance education at Idaho State University. Unpublished doctoral dissertation. Idaho State University. Pocatello, Idaho.

Meyer, K. (2002). Does policy make a difference? An exploration into policies for distance education. Online Journal of Distance Learning Administration, 5(4). Retrieved on February 2, 2005, from: http://www.westga.edu/ distance/ojdla/winter54/Meyer policy $54 . \mathrm{htm}$

Moore, M. (1998). Administrative barriers to adoption of distance education. The American Journal of Distance Education, 8(3), 1-4. 
Murray, B. (2001). What makes students stay. eLearn Magazine. Retrieved from http://elearnmag.org/subpage/sub_page.cfm?article_pk=1301\&page_number_nb=1\&title=FEATURE \%20STORY

Nasser, R. A. (2000). Attitudes and concerns towards distance education: the case of Lebanon. Online Journal of Distance Learning Administration. Retrieved April, 15, 2003, from: http://www.westga.edu/ distance/ojdla/winter34/nasser34.html

Rogers, E. M. (1995). Diffusion of innovation. NY: The Free Press.

Schifter, C. (2002). Perception differences about participating in distance education. Online Journal of Distance Learning Administration. Retrieved April, 14, 2003, from: http://www.westga.edu/ distance/ojdla/spring51/schifter51.html

Simonson, M. (1997). Distance education: Review of the literature. Washington, D.C: Association for Educational Communication and Technology (AECT).

\section{Biography}

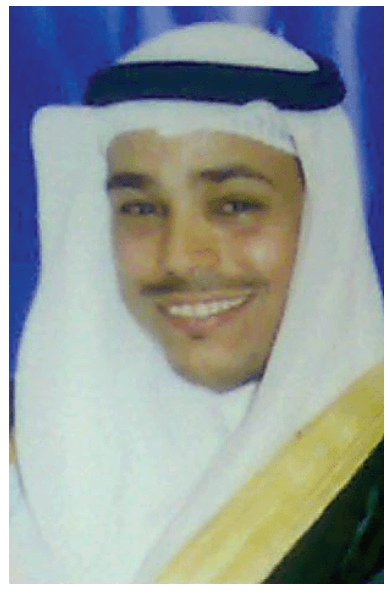

Abdulkarim A. Al Saif received his Batchelor's degree in Science of Arabic Language from Imam Mohammed Bin Saud University ,Qassim, Saudi Arabia, his Masters from Ball State University, Muncie Indiana, and his Ph.D. in Instructional Technology from Wayne State University, Detroit Michigan. From 2005 until the present he has been an assistant professor at the College of Education at the University of Qassim, where the main tasks are: teach pre-service teachers, supervise teacher training, teach undergraduate courses, and serving in research committees. He is also the webmaster of the manahij web site at http://www.manahij.net/, the vice dean of Academic Deanship at University of Qassim, and The founder of Quality Assurance Scientific Association, Saudi Arabia.

His publications and awards include:

2006 : " Students Attitude toward distance education at University of Qassim" published by Journal of European Teacher Network ( JETEN).

2001: Ball State University, Muncie Indiana, Graduate School, Deans' Citation for Academic Excellence.

2001. Ball State University, Muncie Indiana, MSA Service Award.

1998: Al Jazirah Newspaper, Saudi Arabia, several articles about the Modern Arab Literature.

1997: Al Jazirah Newspaper, Saudi Arabia, several articles about contemporary issues in the Modern Arab Literature. 